\title{
Jan Libich, Real-World Economic Policy: Insights from Leading Australian Economists
}

(Cengage Learning Australia, 2015)

\section{Reviewed by Omer Majeed}

The book is a treasure trove of economic policy lessons that brings together some of the brightest Australian economic minds. It caters to a wide audience. For people with no economics background, the book goes a long way in explaining complex issues in a nontechnical and accessible manner. For policymakers, it offers an educational and comprehensive account of how some of the farreaching policies were developed in Australia. For both young and established economists, it will spur them to think about interesting policy topics and consider different economic rationales. Finally, the book offers a novel way of presenting a dialogue on policy issues by means of interviews, and through questions raised by members of the audience present during the interview.

The discussions on designing effective microeconomic policy are particularly helpful for policymakers. Using the baby bonus as an illustration, the contributors show how public policy can create perverse incentives. Their discussions reveal how thousands of births were scheduled so that parents could qualify for the baby bonus. Clearly, in designing policy, the government should be mindful of 'introduction effects'. Importantly, the discussion puts a strong emphasis on holistically thinking through the impacts of policies, including the indirect, second-round effects.

Bob Gregory adds valuable insights about how to think about policy, and how politics interacts with economics. Gregory suggests a useful heuristic for all policymakers: don't just consider the effect of a policy, but also look at the 
counterfactual of either no policy (or an alternative policy) and then do a costbenefit analysis to choose the best option. Gregory's counsel to be flexible in policy rather than rigidly applying textbook remedies is important. The example given in the book includes using both the monetary policy and fiscal policy to fight recessions and then looking at the context and the economic situation of each country to figure out what type of policy is needed more. One thing the chapter could have explored more is a deeper discussion on the strengths and weaknesses of monetary and fiscal policies and the context in which one should be emphasised over the other.

The chapter on fiscal policy rules provides a discussion on essential rules for fiscal deficit, debt and government size. It also discusses how systems of financial penalties that provide desirable incentives may damage the standing of politicians who institute them. However, this chapter could have also explored the specificity of the rules. For instance, Stephen Kirchner hints at setting the fiscal deficit at 2 per cent of GDP, but there was no discussion about why this particular figure makes more sense than any other number. The chapter also dismissed using fiscal policy to stimulate aggregate demand, which seems a bit incompatible with the evidence showing that fiscal policy played an important role in mitigating the impact of the global financial crises. This notion of not using fiscal policy to stimulate aggregate demand also seems inconsistent with some other chapters of the book that suggest that monetary policy and fiscal policy should be used to complement each other in times of economic crisis.

The chapter on population and ageing further explains how an ageing population and demographic trends will affect the fiscal situation of several countries. It shows how as the ratio of retirees to workers increases, the fiscal deficit is either going to increase or the governments will have to change some of their promises. In particular, the chapter points out that the ratio of workers to retirees has decreased from about six half a century ago to about four (or even three) currently, and then presents forecasts that suggest this value will decrease to around two within the next three decades. The chapter also compares Australia's pension-to-GDP ratio with those of countries such as Germany and Belgium. It explains how a more streamlined, less generous and means-tested Australian pension scheme will only see pensions rising to 5 per cent of GDP as opposed to countries with more generous retirement schemes: in Belgium, for example, pensions will rise to 17 per cent of GDP in the coming decades.

The chapter on climate change eloquently argues why and how global warming is a man-made phenomenon, why it is cheaper to mitigate the effects of greenhouse gases than to bear the consequences of global warming and why a price on carbon (that is, a carbon tax or an emissions trading scheme) is less costly and more effective than the case-by-case regulation of the current government's Direct Action policy. The chapter also illustrates how greenhouse 
gases exert negative externality and this has created a situation similar to the prisoner's dilemma, where rational countries may not cooperate, even if they are better off collectively with cooperation.

The chapter discussing the past and future of monetary policy focuses more on the history of central banks than on the economic challenges that central banks face. However, it does look into important discussions of how monetary policy works and how automatic fiscal stabilisers (for example, an independent body managing GST) could be used to complement monetary policy. A more detailed discussion of the GFC and the impacts of negative gearing would have been a valuable addition to the chapter.

In the chapter on banking, financial markets and crises, there is not enough empirical proof given to suggest the specific policy push in the chapter would be beneficial. For instance, Michael Know underplays the importance of fiscal stimulus even when Jan Libich provides evidence based on the results from the International Monetary Fund that the fiscal multiplier during the global financial crises was between 1 and 1.7. The chapter advocates using monetary policy heavily, even pushing the official interest rate to zero, significantly downplaying the impact of liquidity traps - which says that monetary policy is ineffective once interest rates get close to zero. The policies mentioned in the chapter are in stark contrast to the views of people like Paul Krugman, who advocates a much bigger fiscal focus once an economy is found to be in a liquidity trap. Know also does not seem to think that there should be penalties on stakeholders in the financial markets for undertaking unnecessary risks. Not punishing those who take massive, economy-wide risks for higher profits will lead to the problem of moral hazard and may leave the door open for further financial crises. The chapter, however, rightly points out that, in order to avoid breaking legislative rules, the banks often move risky assets off their balance sheets. The chapter importantly highlighted concerns surrounding high debtto-GDP ratios, which may put economies at risk.

The chapter entitled 'The 2008 Global Financial Turmoil: An Inside Policy View' provides further analysis on the global financial crises. It highlights how the lowering of interest rates by the US Fed for an extended period following the dot-com crises in 2001 led to asset bubbles. The chapter recommends targeting nominal income growth rather than targeting inflation. While it provides a brief explanation of why targeting inflation could be more problematic because it is harder to forecast; an in-depth analysis of switching from inflation targeting to income targeting could have added extra value to the chapter. The chapter accurately emphasises the importance of having strong and independent institutions such as central banks, productivity commissions and autonomous Congressional budget offices to provide scrutiny and oversight of the general macroeconomic conditions in the economy. 
The chapter on the Euro crisis starts with an analysis of the pros and cons of the Euro union. It explains how the Euro has helped increase trade and reduce transaction costs, before turning its attention to some of the shortcomings of the Euro and the Eurozone. The problems of fiscal unions are also explored in the chapter, including addressing the problem of moral hazard; of how countries in the periphery borrowed and spent recklessly. The chapter then highlights how an ageing population in the Euro area will further test the fiscal limits of the union. There is a useful discussion of how the Euro union removed two important adjustment mechanisms for each individual country. While Jan Libich claims not to be a Eurosceptic, he does not offer a mechanism that could replace adjustments tools such as the exchange rate and monetary policy - tools that may be important for the long-term economic health of the Euro countries.

The chapter on personal savings provides a nice finishing touch to the book. It shifts the focus from economy-wide policies to how economics can help the ordinary person on the street. The chapter provides an average person with an analysis of why having a diversified portfolio is good. The chapter also explains some of the common pitfalls of playing in the currency market and trying to beat the stock market by buying selected stocks.

While several important topics are discussed, the book does not examine in any detail several significant issues: inequality; negative gearing; mining tax; structural shifts in the Australian post-mining boom economy; and the implications for Australia of the slow-down in the Chinese economy. Neither does the book explain how trade price shocks (as a result of the decline in commodity prices) will affect the Australian economy in the long run. Maybe there is room for a follow-up series.

That said, Real-World Economic Policy is an essential read for any person who wants to engage in the Australian economic debate. It also provides readers who do not have an economics background with a clear and accessible introduction to the key economic issues that the Australian economy and the world faces. Each chapter is made accessible by providing a context and motivation. Moreover, there are summaries, key points and highlights of lessons learned at the end of each chapter. The book also stimulates further interest by providing discussion questions and a guide for further reading. And it will further the desire of the economics community to engage the general public on important issues such as climate change, fiscal policy, monetary policy and government debt. 
This text is taken from Agenda, Volume 23 - Number 1, 2016, edited by William Coleman, published 2016 by ANU Press, The Australian National University, Canberra, Australia. 